TATA LOKA

Volume 21 Nomor 1, Februari 2019, 100-114

(C) 2019 Biro PENERBit PlanOlOGi UNDIP

P ISSN 0852-7458- E ISSN 2356-0266

\title{
REKONTEKSTUALISASI HASIL INTEGRASI NILAI BUDAYA DALAM PERENCANAAN KOTA YOGYAKARTA
}

\author{
Recontextualization of Culture Integration Result \\ in Yogyakarta City Planning
}

\section{D.S.B Wardhana ${ }^{1}$ dan P.N Indradjati ${ }^{2}$}

Diterima: 20 Oktober 2017 Disetujui: 16 November 2018

\begin{abstract}
Abstrak: Tahun 2015, UNESCO menginisiasi penyertaan potensi aspek budaya lokal dalam perencanaan kota yang berkelanjutan. Kota Yogyakarta di Indonesia memiliki potensi historis-kultural yang besar yang didukung pula oleh kebijakan UU No. 13 Tahun 2012 tentang Keistimewaan Yogyakarta. Hal ini merupakan keuntungan yang dapat dimanfaatkan dalam perencanaan berbasis budaya sesuai dengan inisiasi UNESCO. Budaya, saat ini masih dilihat sebagai suatu hal yang abstrak dalam pendefinisian, terutama dalam dunia perencanaan. Namun, dengan adanya dukungan undang-undang dan potensi historis-kultural yang dimiliki, mempermudah Kota Yogyakarta untuk melakukan perencanaan kota berbasis budaya dengan tata nilai budayanya yang sesuai dengan keadaan kontemporer saat ini. Penelitian ini bertujuan untuk mengekplorasi sejauh mana integrasi nilai budaya yang dimiliki Kota Yogyakarta dalam proses perencanaan berdasarkan delapan kriteria perencanaan kota berbasis budaya terkait dengan pedoman dan regulasi, kondisi empiris, serta empat belas tata nilai budaya tradisional Yogyakarta. Hasil analisis menunjukkan bahwa 14 tata nilai budaya Yogyakarta, telah sesuai dengan 7 dari 8 prinsip perencanaan kota berbasis budaya (kecuali dalam satu prinsip yakni prinsip connectivity) dan 5 dari 14 tata nilai budaya Yogyakarta memiliki kaitan kohesif dengan 8 kriteria perencanaan berbasis budaya. Namun dalam praktek pelaksanan perencanaan keterkaitan tersebut tidak terjadi/terwujud. Penelitian ini juga memperkuat teori yang menunjukkan bahwa perencanaan berbasis budaya tergantung dari tiga faktor, yakni; potensi budaya, sumberdaya manusia dan terutama kesadaran akan potensi budaya.
\end{abstract}

\section{Keyword in Bahasa: Budaya, Integrasi, Perencanaan Kota, Rekontekstualisasi, Yogyakarta}

Abstract: In 2015, UNESCO initiated the inclusion of local culture into sustainable urban planning and development. Yogyakarta has a great historical-cultural potential, where the city has been named as a special region established under Undang-Undang No. 13/2012. By referring to the UNESCO initiation and Undang-undang No. 13/2012, Yogyakarta has the advantage to initiate the local cultural into its sustainable urban planning and development. Though culture is intangible; but by taking the law enforcement and its historical-cultural potential into Yogyakarta is now eligible to develop a city planning on cultural basis. This research is to explore the integration of Yogyakarta culture into city planning based on 8 aspects of culture based spatial planning, in relation to planning guidance/regulation, empirical condition and 14 cultural values of Yogyakarta. The research shown that 14 Yogyakarta cultural values, in accordance with 7 of the 8 principles of culture based spatial planning (except connectivity principle) and 5 out of 14 cultural values of Yogyakarta has cohesive relationship with 8 aspects of culture based spatial planning, but it is not manifested

\footnotetext{
${ }^{1}$ Program Studi MPWK. Institut Teknologi Bandung

${ }^{2}$ SAPPK. Institut Teknologi Bandung
} 
on the current planning and implementation. This research reinforces that socio cultural basis of planning relief on 3 variables respectively cultural aspect, human resources, and nevertheless the culture awareness.

Keywords: culture, integration, recontextualization, spatial planning, Yogyakarta

\section{PENDAHULUAN}

Miles (2007:75) menyatakan bahwa kota adalah proses berulang (cyclical) dari budaya manusia, dan selanjutnya kota itu sendiri akan menghasilkan budaya kembali, baik baru ataupun lama. Perencanaan kota saat ini masih banyak menggunakan pendekatan fisik dalam prosesnya, sehingga menyebabkan beberapa masalah sosial dan budaya dalam lingkup kota belum dapat diselesaikan secara utuh. Orientasi pada aspek fisik saja menyebabkan pergeseran ruang sosial, khususnya terhadap kepekaan masyarakat pada perkembangan pembangunan kota, yang menurut Prestel (2016) merupakan imbas daripada urban planning eurocentrism. Dibandingkan dengan perencanaan yang saat ini masih berorientasi pada aspek fisik, konsep perencanaan kota dengan konsep nilai budaya bisa menjadi satu pilihan lain dalam menemukan solusi yang terkait permasalahan sosial dan budaya dalam dimensi tata ruang. Budaya sendiri seharusnya merupakan aspek penting dan fundamental dalam sebuah perencanaan kota. Perencanaan kota yang berhasil bisa terlihat ketika dalam prosesnya, menyentuh sensivitas dari budaya lokal kota tersebut, mengintegrasikan engineering sense yang merupakan aspek fisik dan sensory sense yang merupakan aspek non-fisik di dalam prosesnya (Landry, 2006), yang pada akhirnya bisa merefleksikan secara tepat bagaimana kondisi budaya dan sosial masyarakatnya dalam bentuk fisik yang kontemporer dan menghasilkan sense of place yang bisa dirasakan oleh masyarakat yang ada di dalamnya (Lefebvre, 1992; Gleeson, 2003; Young, 2008: 35). Sejalan dengan hal itu, pada Tahun 2015, UNESCO dalam issue paper untuk mengawali HABITAT III, "urban culture and heritage", menyatakan bahwa, krisis yang terjadi pada lingkungan perkotaan saat ini bisa diselesaikan dengan menyertakan budaya lokal menjadi salah satu faktor pendorong atau driving force (UNESCO Task Team for Habitat III, 2015. Urban Culture and Heritage note, hal 2) utama dalam konsep perencanaan dan pengembangan kota disamping untuk meningkatkan pertumbuhan ekonomi kota. Penggunaan konsep budaya ini belum banyak dikembangkan di Indonesia, namun telah banyak diteliti di berbagai negara, sehingga budaya telah dijadikan kata kunci dalam mendefinisikan landasan dasar "New Urban Agenda" (UNESCO Task Team for Habitat III, 2015. Urban Culture and Heritage note, hal 3-4) menuju kota yang maju dalam ekonomi dan berkelanjutan.

Kota Yogyakarta merupakan Kota yang memiliki potensi secara historis-kultural, yang didukung oleh adanya Kesultanan Yogyakarta. Undang-Undang No. 13 tahun 2012 tentang Keistimewaan Yogyakarta, selaras dengan visi dan misi pembangunan Kota Yogyakarta, yaitu menciptakan kehidupan sosial budaya kota, yang menghargai tradisi, perilaku dan tatanan yang bersumber pada nilai-nilai budaya lokal yakni Sangkan Parining Dumadi-Manunggaling Kawulo Lan Gusti, dan Pathok Negoro dengan mempertahankan, meningkatkan atau menciptakan ruang-ruang kota yang mendukung nilai-nilai alam, manusia, sejarah dan budaya maupun tradisi kehidupan masyarakat Yogyakarta. Namun dalam implementasinya, khususnya dalam penataan ruang, masih belum terlihat bagaimana penerapan aspek nilai budaya lokal tersebut diejawantahkan. Oleh karena itu, untuk mewujudkan penataan ruang (rencana tata ruang) Kota Yogyakarta, dibutuhkan kriteria yang tepat dalam merencanakan tata ruang kota berbasis budaya, dan kebutuhan akan rekontektualisasi dari hasil integrasi nilai-nilai tersebut yang sesuai dengan kondisi kotemporer Kota Yogyakarta. 
Tulisan ini terdiri dari tiga bagian. Bagian pertama akan menguraikan definisi dan jenis budaya dalam lingkup tata ruang serta penjelasan karakteristik, prinsip-prinsip yang dipakai dalam perencanaan kota berbasis budaya. Bagian kedua akan membahas mengenai metodologi penelitian yang digunakan. Bagian ketiga menguraikan hasil ekplorasi pedoman-pedoman yang dipakai dalam dimensi tata ruang dan keterkaitannya dengan tata nilai budaya Kota Yogyakarta; keterkaitan kriteria perencanaan berbasis budaya, dan persoalan yang terjadi; serta kriteria yang dibutuhkan dalam perencanaan berbasis budaya di Kota Yogyakarta, sekaligus proses rekontekstualsiasi yang dapat dilakukan.

\section{Budaya Dalam Konteks Tata Ruang}

Konsep budaya dalam perencanaan tata ruang menurut Young $(2008,36)$ merupakan bagian dari non-spatial strategic planning, yakni kajian strategis non-spasial yang tidak bisa dilepaskan dari sebuah perencanaan. Hal ini dicontohkan dalam mengatur beberapa isu sektoral seperti pariwisata, peninggalan sejarah dan marketing perkotaan, yang dapat menjadi pendorong ekonomi kota dan menjadi modal pembangunan di masa yang akan datang. Dalam kajian yang berbeda, perencanaan tata ruang merupakan suatu konsep dalam menata atau membuat sistem dalam sebuah wilayah geografi yang berdampak langsung pada masyarakat. Ketika bersinggungan langsung dengan masyarakat, budaya masyarakat akan mengikuti sistem yang telah dibuat (Abram, 2011). Sistem tersebut akan menentukan entnografi masyarakat menjadi tetap atau berubah dan di akhir akan membuat pola-pola tertentu dalam kehidupan perkotaan (Stevenson, 2003: 26).

Dalam perencanaan berbasis budaya, terdapat tiga hal yang perlu diperhatikan yakni awareness (kesadaran), human resources (sumber daya manusia), dan culture resources (sumber daya budaya). Menurut Østergaard (2005), sumber daya budaya dalam perencanaan kota berbasis budaya, khususnya di Eropa memiliki beberapa variabel, diantaranya: (1) institusi budaya; (2) peninggalan budaya intangible dan tangible; (3) identitas lokal yang terlihat; (4) institusi pendidikan dan peran intelektual; (5) masukan kreatif dari masyarakat lokal, termasuk di dalamnya produk seni, dan aktivitas jasa. Beberapa hal yang perlu diperhatikan dalam perencanaan berbasis budaya tersebut di atas merupakan faktor mutlak, dimana proses perencanaan baru dapat dilaksanakan dengan optimal ketika faktor-faktor tersebut diikutsertakan.

\section{Rekontekstualisasi dan Integrasi}

Rekontekstualisasi hasil integrasi budaya dalam perencanaan kota secara umum dapat dijelaskan sebagai proses perubahan makna nilai budaya yang digunakan dalam proses perencanaan tata ruang yang didapatkan dari hasil integrasi budaya melalui prinsipprinsip yang ditentukan. Perubahan ini dapat berupa perubahan dengan nilai baru atau kembali pada nilai lama (dalam hal ini, nilai yang berkaitan dengan konteks budaya yang lebih responsif dan aplikatif pada keadaan kontemporer yang lebih bertahan). Pertanyaan krusial terkait itegrasi budaya dalam perencanaan tata ruang adalah sejauh mana kebijakan yang ada dapat mendukung proses integrasi nilai-nilai budaya baik fisik maupun non-fisik dalam dalam tata ruang? Van Oers (1998) menyatakan bahwa perubahan makna nilai budaya yang digunakan dalam proses perencanaan tata ruang yang didapatkan dari hasil integrasi nilai budaya setempat bisa dilakukan dengan cara merubah nilai baru atau dengan mengembalikan nilai lama yang telah ada. Kebutuhan rekontektualisasi nilai budaya ini perlu dilakukan berdasarkan paradigma yang terjadi pada saat ini, terutama dalam tata ruang yang perkembangannya tidak lagi mengarah pada nilai-nilai budaya yang dirujuk bersama atau lebih mengutamakan faktor ekonomi, serta lebih mengarah pada konsep praksis yang menekankan adanya hubungan timbal-balik (Alam. 2014). Integrasi nilai 
budaya dalam perencanaan tata ruang, menurut Maraña (2010), hanya bisa dilakukan dalam perencanaan yang menekankan pada peran pemerintah lokal sebagaimana dikemukakan dalam Declaration of the Principles of International Cultural (UNESCO 1966), dimana dikatakan, "Culture is taken as a fundamental dimension of the planning and development process. Sustainable development can only be ensured by integrating cultural factors into the strategies to achieve it." (Maraña 2010; Duxbury, Hosagrahar, dan Pascual 2016). Beberapa kriteria dan prinsip-prinsip perencanaan berbasis budaya berdasarkan pandangan beberapa ahli dapat dilihat pada tabel 1 berikut ini.

Tabel 1. Kriteria Perencanaan Berbasis Budaya

\begin{tabular}{|c|c|c|}
\hline Kriteria & Keterangan & Sumber / Eksponen \\
\hline Plenitude & $\begin{array}{l}\text { Mempertimbangkan potensi budaya lokal yang ada dan } \\
\text { berkembang di daerah tersebut. }\end{array}$ & $\begin{array}{l}\text { Michel Focault }(1984,267) \text {, } \\
\text { Greg Young }(2008,71-76) \text {, } \\
\text { Lewis Mumford }(2016)\end{array}$ \\
\hline Identity & $\begin{array}{l}\text { Di dalamnya terdapat wujud budaya, dalam sebuah } \\
\text { aturan tertulis dan tidak tertulis, dari mitologi atau } \\
\text { aturan yang turun temurun yang berpengaruh pada pola } \\
\text { peletakan dan atau hasil karya seni manusianya baik } \\
\text { dalam simbol maupun konsep tradisional yang telah } \\
\text { ada. }\end{array}$ & $\begin{array}{l}\text { Clifford Geertz(1973), } \\
\text { Koentjaraningrat ( 1979, 2000), } \\
\text { B.D Wortham (2008), } \\
\text { Peter J.M Nas (2011) }\end{array}$ \\
\hline Connectivity & $\begin{array}{l}\text { Budaya menghubungkan pemikiran dan identitas } \\
\text { masyarakat dalam perencanaan, sebagai faktor } \\
\text { penyempurna perencanaan berbasis fisik yang telah ada. }\end{array}$ & $\begin{array}{l}\text { Greg Young (2008, 71-76), } \\
\text { Charles Landry (2006), } \\
\text { Deborah Stevenson (2003, } \\
\text { 2014) }\end{array}$ \\
\hline Diversity & $\begin{array}{l}\text { Keberagaman dan perbedaan budaya bukan menjadi } \\
\text { penghalang budaya lokal, justru bisa memperkaya } \\
\text { budaya lokal di masa yang masa depan. }\end{array}$ & Greg Young (2008) \\
\hline Reflexivity & $\begin{array}{l}\text { Refleksi atas identitas masyarakat ditemukan dari } \\
\text { identitas lokal daerah, modal utama untuk proses } \\
\text { monitoring dan evaluasi dengan tujuan sustainable } \\
\text { creativity. }\end{array}$ & $\begin{array}{l}\text { Barry Smart (1993), Anthony } \\
\text { Giddens (2003) }\end{array}$ \\
\hline Creativity & $\begin{array}{l}\text { Inovasi yang dikembangkan dalam komunitas } \\
\text { masyarakat baik latar belakang akademisi maupun seni } \\
\text { dalam pengembangan kota. }\end{array}$ & Charles Landry (2006) \\
\hline Critical Thinking & $\begin{array}{l}\text { Kemampuan untuk menilai diri sendiri, mengefektifkan } \\
\text { peran masyarakat dalam proses perencanaan kota salah } \\
\text { satunya tujuannya untuk meningkatkan pertumbuhan } \\
\text { ekonomi kota. }\end{array}$ & Greg Young (2008) \\
\hline
\end{tabular}

Kriteria tersebut diatas, seharusnya menjadi bagian dalam proses penyusunan rencana tata ruang kota. Prinsip untuk mengimplementasi atau perwujudan dalam perencanaan kota, dapat dijelaskan dalam tabel 2 berikut ini:

Tabel 2. Perwujudan Prinsip Budaya dalam Perencanaan

\begin{tabular}{|c|c|}
\hline Prinsip & Perwujudan Dalam Proses Perencanaan \\
\hline Plenitude & $\begin{array}{l}\text { Plenitude berkaitan dengan potensi budaya yang ada dalam daerah tersebut, dalam proses } \\
\text { implementasinya, potensi budaya ini bisa terlihat baik dalam kesadaran masyarakat maupun } \\
\text { pemerintah dalam melihat potensi budayanya, lebih lanjut potensi ini juga diwujudkan dalam } \\
\text { aturan baik tertulis maupun yang tidak tertulis, baik dari aturan yang telah ada atau } \\
\text { tradisional maupun aturan yang ada saat ini, dalam hal ini terutama yang berhubungan } \\
\text { dengan perencanaan tata ruang kota. }\end{array}$ \\
\hline Identity & $\begin{array}{l}\text { Prinsip ini dapat dinilai secara langsung dalam, wujud budaya yang terdeskripsikan dalam } \\
\text { aturan tertulis yang berhubungan langsung dengan perencanaan kota, sehingga perencanaan } \\
\text { yang ada, baik saat ini atau kedepannya tetap memperlihatkan identitas budaya lokal yang } \\
\text { ada }\end{array}$ \\
\hline Connectivity & $\begin{array}{l}\text { Prinsip ini lebih mengutamakan dalam implementasi teknis, potensi budaya yang dikaji } \\
\text { dalam prinsip sebelumnya, terlihat dalam kehidupan sehari-hari masyarakat dan juga } \\
\text { dijadikan acuan atau panduan dalam pelaksanaan perencanaan tata ruang kota }\end{array}$ \\
\hline Diversity & Potensi budaya yang ada dalam daerah tersebut juga diperkaya dengan budaya-budaya lain \\
\hline
\end{tabular}




\begin{tabular}{|c|c|}
\hline Prinsip & Perwujudan Dalam Proses Perencanaan \\
\hline & $\begin{array}{l}\text { yang masuk dan berkembang. Dalam hal ini dapat dinilai bagaimana pemerintah maupun } \\
\text { masyarakat lokal menerima dan menjadikan budaya lain tersebut bukan sebagai penghalang } \\
\text { namun lebih melihat sebagai faktor yang memperkaya budaya lokal yang telah ada, hal ini } \\
\text { termasuk bagaimana masyarakat melihat dan mengadopsi perkembangan budaya modern } \\
\text { namun tidak melupakan budaya lokal yang telah ada }\end{array}$ \\
\hline Reflexivity & $\begin{array}{l}\text { Potensi budaya lokal yang terlihat dalam prinsip sebelumnya terlihat dari bagaimana hal ini } \\
\text { juga terefleksikan dari masyarakat ataupun pemerintah membantu mewujudkan hal tersebut } \\
\text { dalam aktivitas maupun kajian lain yang berhubungan dengan nilai budaya. }\end{array}$ \\
\hline Creativity & $\begin{array}{l}\text { Prinsip ini dalam implementasinya berhubungan dengan inovasi yang dikembangkan oleh } \\
\text { akademisi maupun komunitas, maupun lembaga-lembaga yang berhubungan dengan budaya } \\
\text { dalam daerah tersebut, secara teknis dapat dinilai dari jumlah institusi pendidikan dan } \\
\text { komunitas budaya dan kemudian terlihat dalam sikap proaktif pemerintah untuk } \\
\text { mengikutsertakan institusi pendidikan maupun komunitas budaya yang ada. }\end{array}$ \\
\hline $\begin{array}{l}\text { Critical } \\
\text { Thinking }\end{array}$ & $\begin{array}{l}\text { Prinsip ini dapat terlihat dari bagaimana para pemangku kepentingan mengevaluasi proses } \\
\text { perencanaan tata ruang yang ada untuk pengembangan kedepannya }\end{array}$ \\
\hline Sustainability & $\begin{array}{l}\text { Secara teknis prinsip keberlanjutan ini dapat terlihat dari peran pemerintah dalam } \\
\text { menentukan aturan atau regulasi yang berhubungan dengan kesinambungan perencanaan } \\
\text { tata ruang kota dan hubungannya dengan keberlanjutan baik budaya maupun lingkungan }\end{array}$ \\
\hline
\end{tabular}

Di Indonesia banyak dilakukan pendekatan yang mengintegrasikan nilai budaya lokal dalam perencanaan kota, seperti pada Program Penataan dan Pelestarian Kota Pusaka (P3KP). Program ini merupakan program penataan kota dengan pendekatan sosiospasial, dimana P3KP mempunyai fokus pada "kelestarian budaya" dan "keberlanjutan budaya". Pelestarian sendiri menurut P3KP juga mempertimbangkan aspek fisik dan nonfisik budaya, selara dengan pendapat Young (2008), Landry (2006) dan Østergaard ((2005). Namun dalam implementasinya, P3KP lebih menekankan pada pelestarian aspek fisik budaya dalam kota, dengan menguatkan kuantitas situs dengan cara replikasi (salah satunya), yang kemudian dijadikan indikator keberhasilan dalam rencana aksi kota pusaka.

Kota Yogyakarta sebagaimana ditetapkan dalam Undang-Undang No. 13 Tahun 2012 tentang Keistimewaan Yogyakarta, merupakan Ibukota Provinsi Daerah Istimewa Yogyakarta dan memiliki aturan-aturan budaya yang terumuskan dalam 14 tata nilai budaya. Tata nilai ini diatur dalam Peraturan Daerah Istimewa Yogyakarta No. 4 Tahun 2011 tentang Tata Nilai Budaya Yogyakarta, dimana 5 (lima) dari 14 tata nilai budaya tersebut terkait baik secara umum dan khusus dalam dimensi tata ruang. Keempat belas tata nilai budaya tersebut ditunjukkan dalam table 3 berikut ini.

Tabel 3. Tata Nilai Budaya Yogyakarta

\begin{tabular}{llll}
\hline No & \multicolumn{1}{c}{ Tata Nilai } & No & \multicolumn{1}{c}{ Tata Nilai } \\
\hline 1 & Religio-Spriritual & 8 & Mata Pencaharian \\
2 & Moral & 9 & Bahasa \\
3 & Kemasyarakatan & 10 & Kesenian \\
4 & Adat dan Tradisi & 11 & Benda Cagar Budaya dan Kawasan Cagar \\
& & & Budaya \\
5 & Pendidikan dan Pengetahuan & 12 & Kepemimpinan Dan Pemerintahan \\
6 & Teknologi & 13 & Kejuangan Dan Kebangsaan \\
7 & Tata Ruang dan Arsitektur & 14 & Semangat Ke-Yogyakarta-an \\
\hline
\end{tabular}

Sumber: Lampiran Perdais Yogyakarta No. 4 Tahun 2011

Kelima tata nilai (T.N) yang dapat berkaitan langsung dengan perencanaan kota, antara lain adalah; T.N Adat dan Tradisi, T.N Pendidikan dan Pengetahuan, T.N Tata Ruang dan Arsitektur, T.N Benda Cagar Budaya dan Kawasan Cagar Budaya, T.N Semangat Ke-Yogyakarta-an. 


\section{METODE}

Penelitian mengenai rekontekstualisasi hasil integrasi nilai budaya dalam perencanaan Kota Yogyakarta ini menggunakan pendekatan hermeneutika. Penelitian ini merupakan penelitian eksploratif untuk menyelidiki dan menjelaskan fenomena budaya dalam rencana tata ruang sebagai dasar. Analisis deskriptif kualitatif digunakan untuk merumuskan kriteria dan prinsip-prinsip terkait budaya dalam perencanaan kota. Selanjutnya prinsip-prinsip tersebut dikaji dan dikaitkan dengan dasar hukum, pedoman dan regulasi yang berkaitan degan tata ruang dan budaya dengan teknik analisis hermeneutika dan deskriptif kualitatif. Teknik analisis perbandingan tetap dilakukan untuk melihat kesesuaian pola yang ada dengan kondisi empiris pada dokumen perencanaan dan kriteria yang dibutuhkan dalam perencanaan kota berbasis budaya di Kota Yogyakarta, dengan melihat potensi dan persoalan yang ada.

Pengumpulan data dari sumber primer dilakukan dengan menggunakan survei lapangan dan wawancara. Responden dipilih secara purposive dan snowball sampling, dimana responden dipilih berdasarkan pertimbangan penguasaan subjek ataupun objek yang diteliti serta rekomendasi berdasarkan responden sebelumnya. Responden terpilih terdiri dari tokoh di instansi Pemerintah Kota Yogyakarta, terdiri dari jajaran Satuan Kerja Perangkat Daerah (SKPD) yang terdiri dari Badan Pembangunan Daerah (Bappeda), Dinas Kebudayaan, Dinas Pendidikan Dinas Kependudukan dan Catatan Sipil, Badan Pemberdayaan Perempuan dan Lembaga Swadaya Masyarakat, Dinas Pekerjaan Umum, Dinas Pertanahan dan Tata Ruang, Balai Pelestarian Nilai Budaya Kota. Responden lainnya berasal dari tokoh masyarakat atau tokoh budaya dan/atau akademisi yang ada di Kota Yogyakarta. Pengumpulan data sekunder dilakukan dengan survei instansional untuk mendapatkan data-data rencana tata ruang, peraturan terkait rencana tata ruang dan budaya.

\section{Analisis Dasar Hukum}

Di Indonesia, terdapat beberapa peraturan terkait penataan ruang dan budaya. Penataan Ruang dengan Undang-undang No. 26 Tahun 2007 dan aturan pelaksanaannya serta Undang-undang No. 11 Tahun 2010 tentang Cagar Budaya dan aturan pelaksanaannya. Di Kota Yogyakarta sendiri, terdapat berbagai peraturan budaya dan tata ruang yang seolah-olah berdiri sendiri tidak saling terkait. Dari sisi penataan ruang, beberapa peraturan perundangan tersebut dari sisi substansi menunjukkan keterkaitan dengan prinsip-prinsip perencanaan berbasis budaya dan tata nilai budaya Yogyakarta yang telah dijelaskan sebelumnya.

Tabel 4. Keterkaitan Prinsip Berbasis Budaya Dengan Dasar Hukum dan Tata Nilai Budaya Yogyakarta

\begin{tabular}{|c|c|c|}
\hline $\begin{array}{c}\text { Prinsip-prinsip Perencanaan } \\
\text { Berbasis Budaya }\end{array}$ & Keterkaitan Dasar hukum & $\begin{array}{l}\text { Keterkaitan Tata nilai Budaya } \\
\text { Yogyakarta }\end{array}$ \\
\hline Plenitude & $\begin{array}{l}\text { - Undang-Undang No. } 13 \text { Th. } \\
2012 \text { tentang Keistimewaan } \\
\text { Yogyakarta } \\
\text { - Perdais No. } 4 \text { Th. } 2011 \text { tentang } \\
\text { Tata Nilai Budaya Yogyakarta } \\
\text { - Perdais No. } 1 \text { Th. } 2015 \text { tentang } \\
\text { Kewenangan dalam Urusan } \\
\text { Keistimewaan Yogyakarta }\end{array}$ & 14 tata nilai budaya Yogyakarta \\
\hline Identity & $\begin{array}{l}\text { - Undang-Undang No. } 13 \text { Th. } \\
2012 \text { tentang Keistimewaan } \\
\text { Yogyakarta } \\
\text { - Perdais No. } 4 \text { Th. } 2011 \text { tentang }\end{array}$ & 14 tata nilai budaya Yogyakarta \\
\hline
\end{tabular}




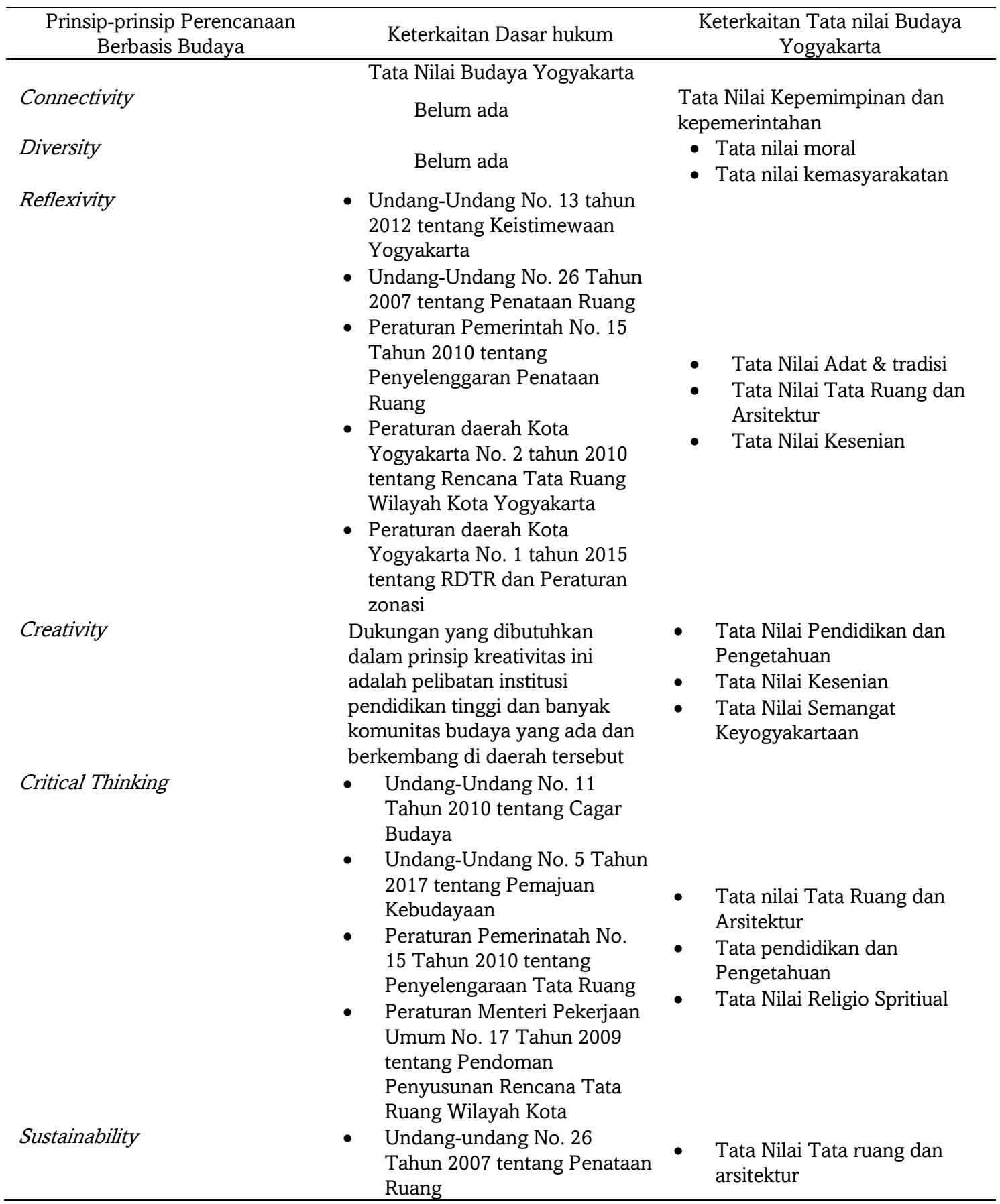

Tabel 4 diatas dan sintesis wawancara yang dilakukan menunjukkan kendala dan permasalahan yang terjadi terkait upaya perwujudan rencana tata ruang berbasis budaya. Yang paling mendasar adalah adanya perbedaan dari teori ideal perencanaan berbasis budaya, dimana pemerintah daerah sebagai salah satu pemangku kepentingan dalam proses perencanaan kota masih belum optimal dalam mengartikan aspek nilai budaya dalam perencanaan kota. Kondisi ini berkebalikan dengan pemahaman akademisi sebagai salah satu pemangku kepentingan dalam perencanaan tata ruang, selain perbedaan dalam menginterpretasikan dan menerjemahkan budaya dalam rencana tata ruang. Kendala lain adalah proses perencanaan pada Pemerintahan Daerah Kota Yogyakarta sendiri yang hingga saat ini masih bersifat sektoral, sehingga kebutuhan perencanaan berbasis budaya 
yang membutuhkan keterlibatan secara holistik dari masing-masing pemangku kepentingan masih belum terlaksana dengan baik.

Dari sisi ketentuan penyusunan rencana tata ruang, pedoman penyusunan rencana tata ruang sebagai acuan dasar dalam proses perencanaan kota, masih belum menyentuh aspek budaya yang intangible atau non-fisik. Hal ini terlihat pada Undang-undang No. 26 tahun 2007 tentang Penataan Ruang, Peraturan Pemerintah No. 15 tahun 2010 tentang Penyelenggaraan Penataan Ruang beserta Peraturan Menteri ATR/BPN No. 37 tahun 2016 tentang peraturan penyusunan kawasan strategis, dan Peraturan Menteri Pekerjaan Umum No. 17 Tahun 2009 tentang Pedoman Penyusunan Rencana Tata Ruang Kota. Dalam peraturan perundangan tersebut, budaya hanya dilihat dalam dalam kerangka fisik atau tangible yang hanya dikaitkan dengan cagar budaya yang juga diatur dalam Undangundang No. 11 tahun 2010 tentang Cagar Budaya.

\section{Analisis Integrasi Nilai Budaya dalam Produk Rencana Tata Ruang}

Integrasi nilai budaya dalam produk rencana tata ruang merupakan proses menghubungkan nilai budaya dalam proses perencanaan kota, sehingga dapat diimplementasikan. Terdapat empat hal yang harus diperhatikan dalam mewujudkan rencana tata ruang berbasis budaya, yaitu aspek legal pengaturan tata ruang dan budaya yang ditetapkan; proses dan produk (materi yang diatur dalam rencana tata ruang); kriteria dan prinsip-prinsip perencanaan berbasis budaya; serta tata nilai budaya lokal. Perbandingan antara tata nilai budaya lokal, kriteria dan prinsip-prinsip perencanaan berbasis budaya dengan peraturan perundangan dan pedoman penyusunan rencana tata ruang seringkali tidak berkesesuaian untuk mewujudkan nilai-nilai budaya dalam ruang kota, sehingga menimbulkan berbagai persoalan dalam mewujudkan Kota Yogyakarta yang berbasis budaya. Persoalan ini muncul tidak hanya karena ketidaksesuaian antara 'keinginan' kota atas nilai-nilai budaya dengan proses atau produk yang dihasilkan oleh rencana tata ruang kota, tetapi juga disebabkan karena keterbatasan dan tidak mudahnya pemangku kepentingan dalam 'menterjemahkan' nilai-nilai budaya lokal dalam substansi rencana tata ruang.

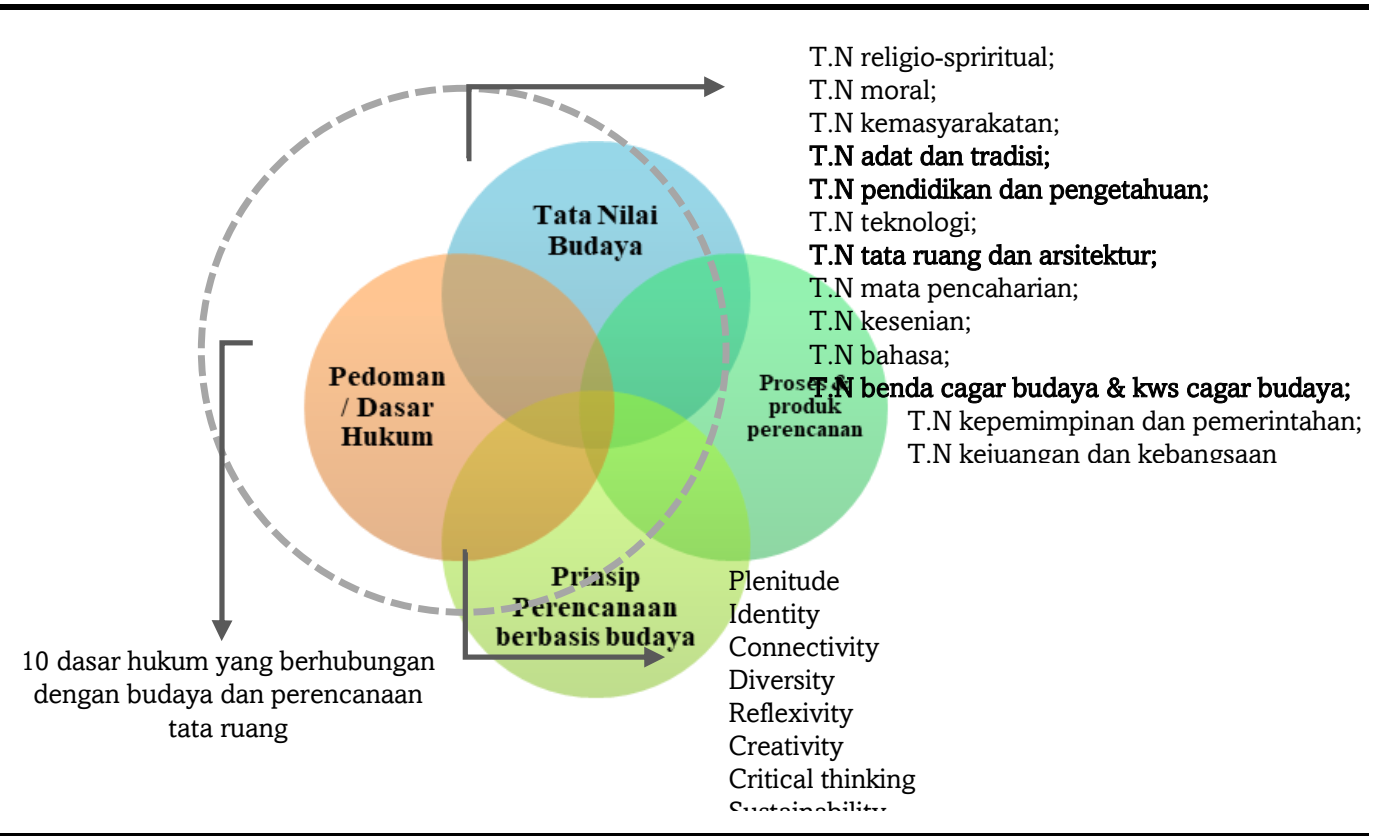

Gambar 1. Proses Integrasi Nilai Budaya dalam Perencanaan Kota 
Aspek budaya dalam materi teknis Rencana Tata Ruang Wilayah Kota Yogyakarta 2010-2029, diatur sebagai berikut:

1. Dalam rencana pengembangan kawasan lindung setempat/arkeologis. Kebijakan perlindungan dan pengembangannya diarahkan melalui pengelolaan obyek wisata budaya dan ilmu pengetahuan untuk pelestarian aset budaya dan pariwisata; dan, pengendalian budidaya di dalam suatu lingkungan cagar budaya atau ilmu pengetahuan untuk mencapai perlindungan maksimal terhadap pelestarian fungsi, kondisi fisik maupun aset budaya yang ada, untuk mendukung Kota Yogyakarta sebagai kota pendidikan, pariwisata dan budaya, sehingga fungsi penyangga menjadi benar-benar signifikan.

2. Salah satu tujuan penataan ruang Kota Yogyakarta adalah terciptanya kehidupan sosial budaya kota yang menghargai tradisi, perilaku, dan tatanan yang bersumber pada nilai "memayu hayuning bawono" dengan mempertahankan, meningkatkan, atau menciptakan ruang-ruang kota yang mendukung nilai-nilai sejarah, budaya maupun tradisi kehidupan masyarakat. Tujuan ini menekankan pada pelestarian budaya dalam tata ruang yang bukan saja mempertimbangkan aspek budaya fisik namun juga adat tradisi (budaya non-fisik). Namun dalam rencana tata ruang hanya difokuskan pada perencanaan aspek fisik budaya seperti situs sejarah maupun cagar budaya. Dalam tujuan penataan struktur disebutkan untuk mempertahankan keberadaan kawasan lindung serta mengoptimalkan potensi sumber daya alam dengan tetap memperhatikan azas kelestarian, dan budaya setempat. Dalam penjelasan terkait rencana pada kawasan cagar budaya lebih difokuskan pada pelestarian dan revitalisasi bangunan tua, bangunan bernilai sejarah dan/atau bernilai arsitektur, serta potensi sosial budaya masyarakat yang memiliki nilai sejarah. Terkait kawasan strategis inti citra kota, kriteria untuk menentukan komponen fisik yang mempunyai citra kota sebagai inti pelestarian didasarkan pada:

a. Nilai filosofis dan atau religius-kultural;

b. Nilai sejarah perjuangan bangsa;

c. Nilai semangat dan kawasan dan wawasan kebangsaan;

d. Nilai seni, keindahan dan sifat khas;

e. Nilai arkeologi

Keterkaitan prinsip perencanaan berbasis budaya, tata nilai budaya Yogyakarta dengan RTRW Kota Yogyakarta lebih rinci dapat dilihat dalam tabel berikut:

Tabel 5. Keterkaitan Prinsip Perencanaan Berbasis Budaya, Tata Nilai Budaya Yogyakarta dengan RTRW Kota Yogyakarta

\begin{tabular}{|c|c|c|c|}
\hline $\begin{array}{c}\text { Prinsip } \\
\text { Perencanaan } \\
\text { Berbasis Budaya }\end{array}$ & $\begin{array}{c}\text { Penerapan dalam } \\
\text { RTRW Kota } \\
\text { Yogyakarta }\end{array}$ & $\begin{array}{c}\text { Keterkaitan dengan } \\
\text { Tata Nilai Budaya } \\
\text { Yogyakarta }\end{array}$ & Penjelasan \\
\hline Plenitude & $\checkmark(*)$ & $\begin{array}{l}\text { Telah sesuai dengan } 5 \\
\text { dari } 14 \text { tata nilai } \\
\text { budaya Yogyakarta } \\
\text { yang berkaitan dengan } \\
\text { perencanaan tata } \\
\text { ruang kota Yogyakarta, } \\
\text { diantaranya: } \\
\text { 1. tata nilai adat dan } \\
\quad \text { tradisi; } \\
\text { 2. tata nilai tata } \\
\quad \text { ruang dan } \\
\quad \text { arsitektur; }\end{array}$ & $\begin{array}{l}\text { Dalam dokumen rencana tata ruang } \\
\text { telah menyertakan aspek sosial } \\
\text { budaya dalam perencanaan dengan } \\
\text { melihat potensi yang ada di Kota } \\
\text { Yogyakarta, baik filosofis maupun tata } \\
\text { nilai. Namun, dalam penjelasannya } \\
\text { masih terbatas pada aspek nilai } \\
\text { budaya yang bersifat fisik, yakni situs } \\
\text { cagar budaya, hal ini dapat terlihat } \\
\text { lebih jelas pada bagian rencana } \\
\text { struktur maupun pola ruang dengan } \\
\text { tujuan yang memiliki perbedaan }\end{array}$ \\
\hline Identity & $\checkmark$ & $\begin{array}{l}\text { 3. tata nilai benda } \\
\text { cagar budaya }\end{array}$ & $\begin{array}{l}\text { Ke-khasan identitas Kota Yogyakarta } \\
\text { telah banyak dijadikan acuan dalam }\end{array}$ \\
\hline
\end{tabular}




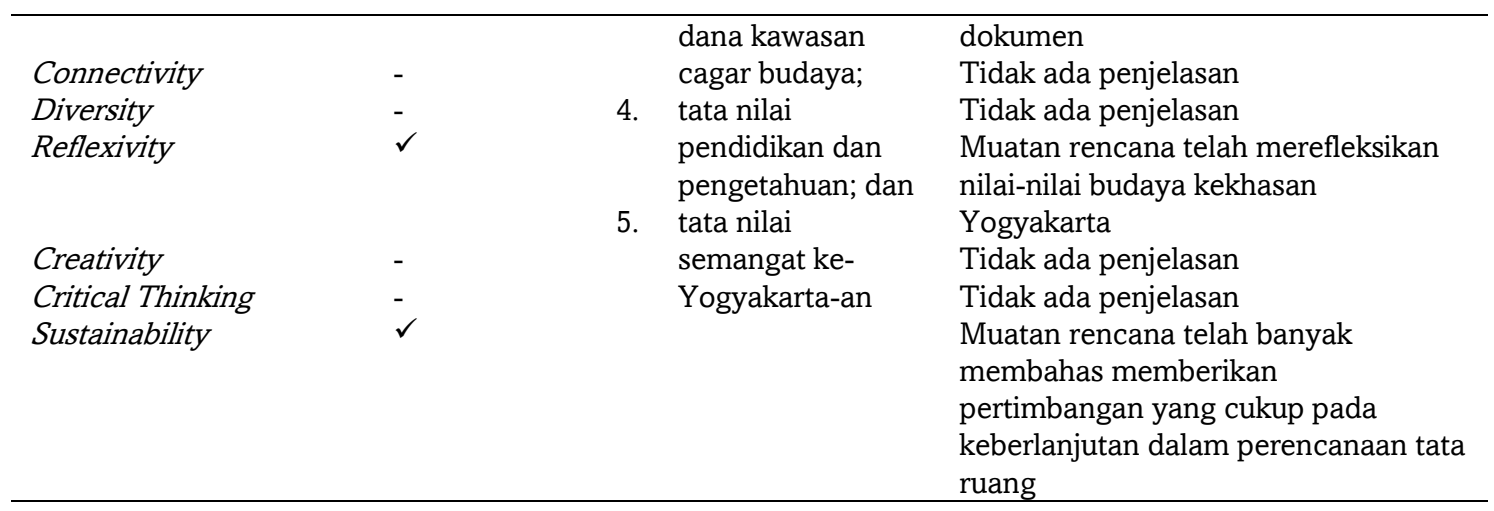

Merujuk keterkaitan tersebut diatas dan hasil wawancara, menunjukkan bahwa saat ini Kota Yogyakarta telah mempertimbangkan nilai filosofis dan religius-kultural dalam konsep perencanaan tata ruangnya. Kondisi ini sesuai dengan prinsip pertama perencanaan berbasis budaya dalam perencanaan kota, yakni plenitude, dan juga sesuai dengan tata nilai budaya Kota Yogyakarta. Namun jika dilihat dari kriteria penetapan citra kota, yakni akar budaya dan masyarakat, berdasarkan kondisi empiris akar budaya masih terlihat hanya dipertimbangkan dalam kajian aspek fisik budaya saja. Sedangkan pelibatan masyarakat dalam perencanaan tata ruang hingga saat ini masih belum banyak dilakukan. Pelibatan masyarakat belum komprehensif dan hanya dilakukan pada beberapa perwakilan dari masyarakat.

Pengendalian pemanfaatan ruang yang diatur dalam RTRW Kota Yogyakarta mengatur ketentuan untuk memperhatikan nilai sosial budaya masyarakat, namun dalam bagian anjuran, variansi dan perubahan pemanfaatan ruang sama sekali tidak menyentuh aspek nilai sosial budaya masyarakat yang telah dijelaskan sebelumnya dalam PERDAIS No. 4 tahun 2011 tentang Tata Nilai Budaya Yogyakarta. Aturan dalam pengendalian pemanfaatan ruang bersifat makro karena menggunakan acuan PP No. 26 tahun 2008 tentang RTRWN (sebagaimana diubah dengan PP No. 13 Tahun 2017).

Secara konseptual dan materi, RTRW Kota Yogyakarta telah memenuhi dan mewadahi beberapa prinsip-prinsip perencanaan berbasis budaya. Jika dikaitkan dengan tata nilai budaya Yogyakarta, RTRW Kota Yogjakarta telah memenuhi kelima tata nila budaya Yogyakarta yang berhubungan dengan tata ruang, yakni, (1) tata nilai adat dan tradisi; (2) tata nilai tata ruang dan arsitektur; (3) tata nilai benda cagar budaya dana kawasan cagar budaya; (4) tata nilai pendidikan dan pengetahuan; dan (5) tata nilai semangat ke-Yogyakarta-an namun dalam penjelasan rencana-nya belum banyak memuat penjelasan aspek budaya terutama dalam kajian non-fisik yang membutuhkkan elemenelemen fisik kota.

\section{Kebutuhan Integrasi Nilai-nilai Budaya dalam Perencanaan Kota Yogyakarta}

Integrasi nilai-nilai budaya dalam perencanaan kota membutuhkan berbagai perubahan dalam pendekatan maupun proses penyusunan rencana tata ruang terkait substansi yang harus dikandung dan dikaji, data, kebutuhan analisis dan juga ahli yang dibutuhkan dalam proses penyusunan rencana tata ruang Kota Yogyakarta. Beberapa substansi tersebut didasarkan pada kesadaran (awareness), sumber daya budaya (cultural resources), inovasi, keberlanjutan budaya dan lingkungan, sumber daya manusia (human resources) dan pedoman dan kebijakan hukum (legal basis) seperti yang terlihat dalam Tabel.6 berikut ini. 
Tabel 6. Materi yang Dibutuhkan dalam Perencanaan Berbasis Budaya

\begin{tabular}{|c|c|c|c|c|}
\hline $\begin{array}{c}\text { Kriteria } \\
\text { Spesifik } \\
\text { Perencanaan } \\
\text { Berbasis } \\
\text { Budaya }\end{array}$ & Input Data & Kebutuhan Analisis & Keluaran Analisis & $\begin{array}{c}\text { Pemangku } \\
\text { Kepentingan } \\
\text { yang Berperan }\end{array}$ \\
\hline $\begin{array}{l}\text { Dasar Hukum, } \\
\text { kebijakan, } \\
\text { Pedoman dan } \\
\text { Standard }\end{array}$ & $\begin{array}{l}\text { Pedoman, } \\
\text { kebijakan, dasar } \\
\text { hukum dan } \\
\text { standard yang } \\
\text { berkaitan dengan } \\
\text { tata ruang dan } \\
\text { budaya, dengan } \\
\text { berlandaskan } \\
\text { kesadaran awal } \\
\text { akan } \\
\text { Keistimewaan } \\
\text { daerah }\end{array}$ & $\begin{array}{l}\text { - Baik pedoman, dasar } \\
\text { hukum, kebijakan } \\
\text { maupun standar yang } \\
\text { mengatur tentang tata } \\
\text { ruang harus dikaitkan } \\
\text { dengan keberadaan Kota } \\
\text { Yogyakarta sebagai satu- } \\
\text { satunya daerah istimewa } \\
\text { dengan potensi historis- } \\
\text { kultural } \\
\text { - Dengan adanya UU } \\
\text { 13Tahun 2012, yang } \\
\text { berfokus pada } \\
\text { kewenangan Kesultanan } \\
\text { Yogyakarta, menjadi } \\
\text { sebuah keuntungan } \\
\text { karena dapat lebih fokus } \\
\text { dan detail dalam } \\
\text { perencanaan tata ruang } \\
\text { berbasis budaya terutama } \\
\text { dalam kaitannya dengan } \\
\text { sektor-sektor khusus yang } \\
\text { bersinggungan langsung } \\
\text { dengan perencanaan tata } \\
\text { ruang Kota Yogyakarta }\end{array}$ & $\begin{array}{l}\text { - Produk kebijakan } \\
\text { dalam dokumen, } \\
\text { Perdais yang lebih } \\
\text { fokus dalam } \\
\text { melihat budaya } \\
\text { dari aspek fisik } \\
\text { maupun non-fisik } \\
\text { - Pelibatan } \\
\text { akademisi maupun } \\
\text { komunitas budaya } \\
\text { untuk lebih } \\
\text { memanfaatkan } \\
\text { potensi SDM yang } \\
\text { ada di Kota } \\
\text { Yogyakarta } \\
\text { - Aturan bagi } \\
\text { Kesultanan } \\
\text { ataupun balai } \\
\text { pelestarian yang } \\
\text { lebih kuat dalam } \\
\text { hal yang } \\
\text { berhubungan } \\
\text { dengan budaya } \\
\text { non-fisik dalam } \\
\text { tata ruang atau } \\
\text { aspek yang } \\
\text { berkaitan dengan } \\
\text { budaya }\end{array}$ & $\begin{array}{l}\text { - Pemerintah } \\
\text { Provinsi dan } \\
\text { Kota } \\
\text { - Kesultanan } \\
\text { Yogyakarta } \\
\text { - Akademisi } \\
\text { baik dalam } \\
\text { aspek hukum, } \\
\text { tata ruang, } \\
\text { dan budaya } \\
\text { - Balai } \\
\text { pelestarian } \\
\text { budaya } \\
\text { - Komunitas } \\
\text { budaya }\end{array}$ \\
\hline Budaya Fisik & $\begin{array}{l}\text { Produk budaya } \\
\text { berupa: } \\
\text { - Situs cagar } \\
\text { budaya } \\
\text { - Bangunan } \\
\text { bersejarah } \\
\text { - Produk } \\
\text { kesenian } \\
\text { - Upacara adat }\end{array}$ & $\begin{array}{l}\text { - Melakukan pendataan } \\
\text { baik kuantitas maupun } \\
\text { kualitas produk budaya } \\
\text { berupa fisik atau tangible } \\
\text { - Melakukan konservasi } \\
\text { dan revitalisasi produk- } \\
\text { produk budaya fisik yang } \\
\text { ada di kota Yogyakarta, } \\
\text { yang tidak terbatas pada } \\
\text { peningkatan kuantitas } \\
\text { namun juga dari aspek } \\
\text { kualitas } \\
\text { - Menghubungkan hasil } \\
\text { analisis ini dengan } \\
\text { keluaran hasil analis hasil } \\
\text { produk budaya non-fisik } \\
\text { untuk melihat } \\
\text { kesesuaiannya secara } \\
\text { filosofis maupun } \\
\text { kosmologis }\end{array}$ & $\begin{array}{l}\text { Data potensi produk } \\
\text { budaya fisik baik } \\
\text { berupa situs, cagar, } \\
\text { dan kawasan budaya } \\
\text { yang selalu } \\
\text { dihubungkan dengan } \\
\text { aspek filosofis yang } \\
\text { ada pada data-data } \\
\text { aturan yang } \\
\text { mengatur tata nilai } \\
\text { budaya terutama } \\
\text { kaitannya dalam } \\
\text { aturan dan produk } \\
\text { dokumen } \\
\text { perencanaan }\end{array}$ & $\begin{array}{l}\text { - Pemerintah } \\
\text { Kota } \\
\text { - Balai } \\
\text { Pelestarian } \\
\text { nilai budaya } \\
\text { - Kesultanan } \\
\text { Yogyakarta } \\
\text { - Akademisi }\end{array}$ \\
\hline $\begin{array}{l}\text { Budaya Non- } \\
\text { fisik }\end{array}$ & $\begin{array}{l}\text { Produk budaya } \\
\text { berupa: } \\
\text { - Peraturan } \\
\text { tertulis } \\
\text { - Peraturan tidak } \\
\text { tertulis } \\
\text { - Filosofi }\end{array}$ & $\begin{array}{l}\text { Pencatatan dan } \\
\text { pendataan ulang segala } \\
\text { peraturan tidak tertulis } \\
\text { dan tertulis baik berupa } \\
\text { tata aturan budaya yang } \\
\text { ada dan dijadikan } \\
\text { kebiasaan secara turun }\end{array}$ & $\begin{array}{l}\text { Data potensi produk } \\
\text { budaya non-fisik baik } \\
\text { berupa aturan tertulis } \\
\text { dan tidak tertulis, } \\
\text { filosofi dan } \\
\text { kosmologi, serta } \\
\text { kebiasaan budaya }\end{array}$ & $\begin{array}{l}\text { - Pemerintah } \\
\text { Kota } \\
\text { - Balai } \\
\text { Pelestarian } \\
\text { nilai budaya } \\
\text { - Kesultanan } \\
\text { Yogyakarta }\end{array}$ \\
\hline
\end{tabular}




\begin{tabular}{|c|c|c|c|c|}
\hline $\begin{array}{c}\text { Kriteria } \\
\text { Spesifik } \\
\text { Perencanaan } \\
\text { Berbasis } \\
\text { Budaya }\end{array}$ & Input Data & Kebutuhan Analisis & Keluaran Analisis & $\begin{array}{c}\text { Pemangku } \\
\text { Kepentingan } \\
\text { yang Berperan }\end{array}$ \\
\hline & $\begin{array}{l}\text { - Kosmologi } \\
\text { - Kebiasaan }\end{array}$ & $\begin{array}{l}\text { temurun } \\
\text { Hasil keluaran selalu } \\
\text { dihubungkan dengan } \\
\text { hasil keluaran analisis } \\
\text { budaya fisik, sebagai } \\
\text { masukan atau sebagai } \\
\text { alat kendali kesesuaian } \\
\text { dengan tata aturan nilai- } \\
\text { nilai budaya Kota } \\
\text { Yogyakarta }\end{array}$ & $\begin{array}{l}\text { yang selalu } \\
\text { dihubungkan dengan } \\
\text { data potensi budaya } \\
\text { fisik, terutama } \\
\text { kaitannya dalam } \\
\text { aturan dan produk } \\
\text { dokumen } \\
\text { perencanaan }\end{array}$ & - Akademisi \\
\hline Inovasi & $\begin{array}{l}\text { Penelitian yang } \\
\text { berkaitan dengan } \\
\text { tata ruang dan } \\
\text { budaya dari setiap } \\
\text { sumber daya yang } \\
\text { berkaitan }\end{array}$ & $\begin{array}{l}\text { - Kajian penelitian yang } \\
\text { berhubungan dengan } \\
\text { budaya dan tata ruang } \\
\text { lebih memaksimalkan } \\
\text { perannya } \\
\text { - Pengkayaan pengetahuan } \\
\text { perlu ditingkatkan baik } \\
\text { oleh masing-masing } \\
\text { pemangku kepentingan }\end{array}$ & $\begin{array}{l}\text { Inovasi dan kajian- } \\
\text { kajian lain yang } \\
\text { berhubungan dengan } \\
\text { tata ruang budaya } \\
\text { Yogyakarta dalam } \\
\text { lingkup saat ini dan } \\
\text { masa depan }\end{array}$ & $\begin{array}{l}\text { - Akademisi } \\
\text { - Komunitas } \\
\text { budaya } \\
\text { - Pemerintah } \\
\text { daerah }\end{array}$ \\
\hline $\begin{array}{l}\text { Keberlanjutan } \\
\text { budaya dan } \\
\text { lingkungan }\end{array}$ & $\begin{array}{l}\text { Spesifik pada } \\
\text { pelaksanaan } \\
\text { kegiatan budaya } \\
\text { baik secara umum } \\
\text { maupun dalam } \\
\text { konteks tata } \\
\text { ruang yang } \\
\text { dilakukan oleh } \\
\text { masyarakat }\end{array}$ & $\begin{array}{l}\text { Optimalisasi pelibatan } \\
\text { masyarakat dalam hal ini } \\
\text { komunitas budaya yang } \\
\text { tidak hanya terbatas pada } \\
\text { festival-festival kesenian, } \\
\text { dan lebih mendorong } \\
\text { masyarakat untuk lebih } \\
\text { kritis dalam perencanaan } \\
\text { tata ruang berbasis budaya } \\
\text { di Kota Yogyakarta, dimana } \\
\text { saat ini masih melihat } \\
\text { budaya dalam tataran } \\
\text { pariwisata dan ekonomi } \\
\text { kreatif }\end{array}$ & $\begin{array}{l}\text { Keterlibatan } \\
\text { komunitas budaya } \\
\text { dan masyarakat yang } \\
\text { tidak terbatas pada } \\
\text { festival seni yang } \\
\text { hanya berhubungan } \\
\text { dengan pariwisata } \\
\text { dengan tujuan } \\
\text { ekonomi }\end{array}$ & $\begin{array}{l}\text { - Komunitas } \\
\text { budaya } \\
\text { - Masyarakat }\end{array}$ \\
\hline
\end{tabular}

Tabel 6 menunjukkan bahwa kesadaran akan pentingnya menyertakan budaya dalam proses perencanaan di Kota Yogyakarta dibutuhkan sebelum melakukan tahapan-tahapan selanjutnya. Sebagai daerah istimewa yang diatur dalam UU No. 13 tahun 2012 membuat Kota Yogyakarta yang merupakan bagian DIY memiliki keuntungan tersendiri, karena UU tersebut mengatur tentang kewenangan Kesultanan Yogyakarta dalam melakukan tata atur pemerintahan dengan tetap memperhatikan dan mempertahankan nilai-nilai historis kultural yang menjadi alasan utama diterbitkannya UU keistimewaan tersebut.

Kesadaran yang dibutuhkan dalam melihat nilai budaya dalam tata ruang baik dalam proses maupun produk, bukan hanya produk fisik namun juga non-fisik, yang sangat dibutuhkan untuk kelangsungan budaya lokal tersebut tetap menjadi dasar berkehidupan secara umum dan tata ruang secara khusus. Keterlibatan komunitas budaya sebagai bagian dari inovasi harus mempertimbangkan aspek budaya dalam tata ruang dengan tetap melihat kondisi kontemporer, selain pentingnya konsistensi dan hubungan antar sektor dalam dimensi perencanaan berbasis budaya, serta kerjasama dan mempertimbangkan masing-masing substansi yang dikeluarkan oleh para pemangku kepentingan yang terkait. 


\section{HASIL DAN PEMBAHASAN}

Beberapa temuan penelitian terkait integrasi nilai budaya dalam perencanaan kota antara lain, Undang-Undang No. 13 tahun 2012, tentang Keistimewaan Yogyakarta dan juga Undang-Undang pemajuan Kebudayaan No. 5 Tahun 2017 yang seharusnya bisa menjadi faktor yang kuat dalam perencanaan kota berbasis budaya di Kota Yogyakarta hingga saat ini belum dimasukkan dalam dokumen rencana pembangunan jangka panjang daerah Kota Yogyakarta. Beberapa pedoman yang berkaitan dengan proses perencanaan tata ruang masih melihat budaya dalam tataran fisik belum begitu banyak membahas aspek non-fisik budaya, diantaranya; Undang-Undang No. 26 tahun 2007, tentang Penataan Ruang: dalam substansi yang berhubungan dengan budaya, UU No. 26 tahun 2007 ini menyatakan bahwa perencanaan haruslah selaras, serasi dan seimbang, dimana perlu mempertimbangkan hubungan antara aspek manusia dan adat istiadat budaya lokal, namun lebih lanjut dalam lampiran penjelasan UU tersebut tidak dijelaskan secara rinci, sehingga pada akhirnya dapat ditafsirkan sendiri oleh pelaksana dalam hal ini instansi daerah. Undang-Undang No. 11 tahun 2010, tentang Cagar Budaya, berdasarkan hubungan dengan perencanaan nilai budaya, UU ini sedikit mempersempit ruang gerak perencanaan berbasis budaya yang menerjemahkan budaya sebagai suatu hal fisik yang bersifat situs atau peninggalan sejarah fisik, sehingga sebelum adanya UU No. 5 tahun 2017 tentang Pemajuan Kebudayaan, hal non-fisik terutama yang berhubungan dengan perencanaan, sama sekali tidak disinggung.Peraturan Pemerintah N0. 15 Tahun 2010, tentang Penyelenggaraan Penataan Ruang dan Peraturan Menteri ATR/BPN. No. 37 tahun 2016 tentang Pedoman Penyusunan Rencana Tata Ruang Kawasan Strategis Provinsi dan Kawasan Strategis Kabupaten/Kota. Penerjemahan pasal yang mengatur nilai non-fisik budaya terutama dalam Pasal (23), dimana dalam beberapa ayat-nya berbicara mengenai perencanaan lingkungan terbangun dan adat istiadat, namun dalam implementasinya kajian nilai budaya dalam perencanaan Kota Yogyakarta saat ini masih melihat budaya dari perspektif fisikal.

Kurang selarasnya perspektif antarpemangku kepentingan dalam perencanaan tata ruang, baik pemerintah dengan akademisi maupun komunitas, sebagai bagian yang tidak terpisahkan dalam perencanaan kota berbasis budaya. Kondisi ini disebabkan karena perbedaan pemahaman dalam melihat aspek nilai budaya dalam perencanaan dengan masing-masing pendekatan yang dimiliki pemangku kepentingan. Akademisi lebih bersifat scientific dan ideal dalam memberikan gagasan atau wacana, sedangkan pemerintah lebih menggunakan pendekatan praksis yang lebih mudah dan dengan segera diimplementasikan. Selain itu, komunitas sebagai salah satu bagian penting lebih fokus pula pada pelestarian kesenian dan budaya, walaupun dalam perjalanannya ada juga komunitas yang tergabung dalam balai pelestarian nilai budaya Kota Yogyakarta yang fokus pada penelitian tentang aspek nilai budaya dalam tata ruang.

Adanya perbedaan pendekatan yang dilakukan masing-masing individu atau sumber daya manusia pemangku kepentingan yang dalam melihat budaya Kota Yogyakarta sebagai hal yang tidak bisa disertakan dalam proses perencanaan tata ruang. Hasil wawancara menunjukkan bahwa latar belakang, sikap kritis, dan kepedulian lebih dibutuhkan dalam melihat aspek nilai budaya dalam perencanaan tata ruang. Pelibatan masyarakat/komunitas yang ada di dalam proses perencanaan Kota Yogyakarta masih terbatas perwakilan, sehingga belum menyentuh langsung aspirasi dan kepentingan masyarakat dalam proses perencanan tata ruang.

\section{KESIMPULAN}

Dengan melihat faktor sejarah dan budaya yang dimiliki, serta dukungan UndangUndang No. 13 Tahun 2012 tentang keistimewaan Yogyakarta, Kota Yogyakarta memiliki 
potensi besar untuk dapat digunakan sebagai modal perencanaan berbasis budaya. Kota Yogyakarta mempunyai 2 (dua) dari keempat belas prinsip-prinsip perencanaan berbasis budaya, diantaranya yakni Plenitude dan Identity yang fokus pada potensi budaya dan implementasinya telah ada dalam proses perencanaan saat ini. Disisi lain, Kota Yogyakarta telah memiliki 14 tata nilai budaya tradisional yang mengatur keseluruhan segi kehidupan masyarakat Yogyakarta, yang tertuang dalam Lembar Lampiran Peraturan Daerah Istimewa Yogyakarta No. 4 Tahun 2011. Salah satu dari tata nilai tersebut, yakni tata nilai tata ruang dan arsitektur telah sesuai dengan 8 prinsip perencanaan kota berbasis budaya dan keterkaitannya dengan pedoman maupun dokumen perencanaan Kota Yogyakarta telah sesuai terutama dalam penjelasan budaya dalam tataran tata ruang yang tidak hanya membahas implementasi budaya tersebut secara fisik, namun hal ini tidak terjadi pada pelaksanaan di lapangan.

Kajian tentang rekontektualisasi hasil integrasi nilai budaya Yogyakarta didapatkan dari hasil penjodohan pola, dimana keterkaitan 14 tata nilai budaya Yogyakarta, telah sesuai dengan 7 dari 8 prinsip perencanaan kota berbasis budaya, kecuali dalam satu prinsip yakni prinsip connectivity. Connectivity belum sesuai karena prinsip ini mengharuskan antar pemangku kepentingan (dalam perencanaan tata ruang berbasis budaya) memiliki visi yang sama baik dari penerjemahan konsep maupun implementasinya. Proses rekontekstualisasi yang dibutuhkan adalah proses rekontekstualisasi yang mengacu pada nilai budaya lama, karena budaya tradisional yang ada di Kota Yogyakarta dianggap masih sangat relevan dengan keadaan kontemporer. Persoalan yang perlu segera untuk diselesaikan adalah persoalan connectivity yang dirasa sangat penting, karena perencanaan kota dengan basis nilai budaya hanya bisa dilakukan apabila terjadi kesamaan persepsi antar stakeholder yang terlibat dalam proses perencanaan kota dalam melihat nilai budaya tersebut. Perspektif yang perlu disamakan terutama dalam melihat nilai budaya, yang bukan hanya dilihat sebagai suatu yang tangible namun juga suatu hal yang intangible, yang ada dan diwariskan secara turun temurun dalam kehidupan Kota Yogyakarta, dan juga pelibatan aktor lain yang sangat berpengaruh dalam proses perencanaan kota berbasis budaya, yakni akademisi dan komunitas budaya.

\section{DAFTAR PUSTAKA}

Abram, Simone. 2011. Culture and planning. Farnham, Surrey, England; Burlington, VT: Ashgate Pub. Company.

Alam, Bachtiar 2014b. "Globalisasi dan Perubahan Budaya: Perspektif Teori Kebudayaan." Antropologi Indonesia. http://journal.ui.ac.id/index.php/jai/article/viewArticle/3325.

Al-Homoud, Mohammad. 2003. "Sustainable Urban Planning of Historical Jawa - Analysis of the Physical and Social Pattern."

Duxbury, Nancy, Jyoti Hosagrahar, dan Jordi Pascual. 2016. "Why Must Culture be at the Heart of Sustainable Urban Development." United Culture and Local Goverment.

Foucault, Michel, dan Paul Rabinow. 1984. The Foucault reader. 1st ed. New York: Pantheon Books.

Geertz, Clifford. 1973. The interpretation of cultures: selected essays. New York: Basic Books.

Geertz, Clifford, dan Taufik Abdullah. 2013. Agama Jawa: abangan, santri, priyayi dalam kebudayaan Jawa. Depok, Indonesia: Komunitas Bambu.

Giddens, Anthony. 2003. The Consequences of Modernity. Standford: Standford University Press.

Gleeson, B. 2003. Reflexive Modernization: The Re-Enlighment of Planning? International Planning Studies 5: $1,117-135$

J.M Nas, Peter. 2002. "Masterpieces of Oral and Intangible Culture: Reflections on the UNESCO World Heritage List." Current Anthropology 43 (1): 139-48. doi:10.1086/338287.

J.M Nas, Peter. 2011. Cities of full symbol: a theory of urban space and symbol. Amsterdam: Leiden University Press.

Koentjaraningrat. 1979. Pengantar ilmu Antropologi. Jakarta: Rineka Cipta.

Koentjaraningrat. 2000. Kebudayaan, mentalitas dan pembangunan. Jakarta: Gramedia.

Landry, Charles. 2006. The art of city-making. Sterling, VA: Earthscan.

Landry, Charles. 2008. The creative city: a toolkit for urban innovators. 2nd ed. New Stroud, UK: London; Sterling, VA: Comedia ; Earthscan. 
Lefèbvre, Henri. 1992. The Production of Space. Oxford: Blackwell.

Maraña, Maider. 2010. “Culture and Development.” UNESCO Extea Working Paper.

Miles, Malcolm. 2007. Cities and cultures. Routledge critical introductions to urbanism and the city. London; New York: Routledge.

Mumford, Lewis. 2016. The culture of cities. Open Road Media.

Østergaard, Katrine, ed. 2005. Cultural Planning. Bh.: Royal Danish Academy of Fine Arts, School of Architecture: [Eksp. KASB.

Porter, Libby. 2010. Unlearning the colonial cultures of planning. Farnham, England; Burlington, VT: Ashgate Pub. Co

Prestel, Joseph Ben. 2016. "Paris Everywhere? The Challenge of Eurocentrism in Global Urban History." www.globalurbanhistory.com.

Smart, Barry. 1993. Postmodernity. Key ideas. London; New York: Routledge.

Stevenson, Deborah. 2003. Cities and Urban Cultures. Issues in Cultural and Media Studies. Maidenhead: Open University Press.

Stevenson, Deborah. 2014. Cities of culture: a global perspective. Routledge advances in sociology 111. Abingdon, Oxon: Routledge.

UNESCO. 1966. "Declaration of the Principles of International Cultural." Environmental management.

Van Oers, Bert. 1998a. "The Fallacy of Detextualization." Mind, Culture, and Activity 5 (2): 135-42. doi:10.1207/s15327884mca0502_7.

Van Oers, Bert. 1998b. "From Context to Contextualizing." Learning and Instruction 8 (6): 473-88. doi:10.1016/S0959-4752(98)00031-0.

Wortham, Galvin B.D. 2008. "Mythologies of Placemaking." https://placesjournal.org/article/mythologies-ofplacemaking/.

Young, Greg. 2008. Reshaping Planning with Cuture. Urban and regional planning and development series. Aldershot, England; Burlington, VT: Ashgate.

Kementerian Agraria dan Tata Ruang "Peraturan Menteri Agraria dan Tata Ruang/ Kepala Badan Pertanahan Nasional Republik Indonesia No. 37 Tahun 2016, tentang Pedoman Penyusunan Rencana Tata Ruang Kawsan Strategis Provinsi dan Rencana Tata Ruang Kawasan Strategis Kabupaten."

Kementerian Pekerjaan Umum "Peraturan Menteri Pekerjaan Umum No. 15 Tahun 2012, tentang Pedoman Penyusunan Tata Ruang Kawasan Strategis Nasional."

Kementerian Pekerjaan Umum "Peraturan Menteri Pekerjaan Umum No. 17 Tahun 2009 tentang Pedoman Penyusunan Tata Ruang Kota.”

Pemerintah Kota Yogyakarta "Peraturan Daerah Kota Yogyakarta, No. 2 Tahun 2010, tentang Rencana Tata Ruang Wilayah Kota Yogyakarta Tahun 2010-2029."

Pemerintah Provinsi Daerah Istimewa Yogyakarta "Peraturan Daerah Istimewa, Daerah Istimewa Yogyakarta, No. 1 Tahun 2013, tentang Kewenangan Dalam Urusan Kewenangan Daerah Istimewa Yogyakarta."

Pemerintah Provinsi Daerah Istimewa Yogyakarta "Peraturan Daerah Istimewa, Daerah Istimewa Yogyakarta, No. 4 Tahu 2011, tentang Tata Nilai Budaya Yogyakarta.”

Pemerintah Republik Indonesia "Peraturan Pemerintah No. 15 Tahun 2010 tentang Penyelenggaraan Tata Ruang."

Pemerintah Republik Indonesia "Peraturan Pemerintah No. 26 Tahun 2008 tentang Rencana Tata Ruang Wilayah Nasional."

Pemerintah Republik Indonesia "Undang-Undang No. 11 Tahun 2010 tentang Cagar Budaya.”

Pemerintah Republik Indonesia "Undang-Undang No. 13 Tahun 2012 Keistimewaan Daerah Istimewa Yogyakarta."

Pemerintah Republik Indonesia “Undang-Undang No, 26 Tahun 2007 Tentang Penataan Ruang.” 